\title{
Assessment of Bioassay Techniques and Residual Effect of Certain Acaricides against the Two Spotted Spider Mite, Tetranychus urticae Koch and The Predatory Mite, Phytoseiulus persimilis Athias-Henriot
}

\author{
A. E. M. Abd El-Mageed; Alyaa A. Tawfik and Efthhar E. Abohatab \\ Plant Protection Research Institute, Agricultural Research Center, Dokki, Giza, Egypt
}

\begin{abstract}
Experiments were conducted in the laboratory and the greenhouse to assess the effects of five acaricides against Tetranychus urticae Koch and its natural enemy Phytoseiulus persimilis Athias-Henriot. The acaricidal activity of the tested compounds against $T$. urticae was assessed by the slide dip and leaf disk dip techniques. Data showed that slide dip technique was efficient method to screen abamectin, chlorfenapyr and fenpyroximate; while the leaf disk dip technique was efficient method to determine the toxicity of ethion and etoxazole. The difference between the compounds may be due to their mode of actions. Results indicate that ethion, chlorfenapyr and etoxazole are very less toxic to $P$. persimilis adult females than those of $T$. urticae. Direct count for each of the prey and predator in order to assess the impact of compounds tested under greenhouse conditions, confirmed the results obtained to a large extent in the laboratory experiments.
\end{abstract}

Key Words: Bioassay techniques, Acaricides, Tetranychus urticae, Phytoseiulus persimilis.

\section{INTRODUCTION}

Integration of a biological control agent into agricultural IPM systems can not be achieved unless the natural enemy can survive after pesticides application (Hoy 1985). In addition, knowledge of pesticide selectivity to beneficial arthropods is important to its utility in IPM programs, creating better conditions for natural enemies and helping to reduce pesticide applications. Predatory mites of the family Phytoseiidae are effective as biological control agents in agricultural systems (Hoy et al., 1983). Phytoseiulus persimilis Athias-Henriot, is worldwide used in biological control programs in the world (Gerson et al., 2003). It is a major biocontrol agent of webbing spider mites (especially Tetranychus spp.) that infest many crops in greenhouses and open fields (Mcmurtry, 1982). The two-spotted spider mite, Tetranychus urticae Koch, is a major pest of agricultural systems, mainly annual crops and vegetables (Helle \& Sabelis ,1985). Numerous acaricides are used to control this pest, and consequently it has developed resistance to several acaricides. T. urticae outbreaks are induced by a number of factors, frequently by the use of pesticides non-selective towards its natural enemies (Mcmurtry et al., 1970). Consequently, plant pest populations may increase to more damaging levels than occurred before treatment (Croft, 1990). Since resistance to acaricides in $T$. urticae spread rapidly, biological control tactics are crucial to manage spider mite populations (Gerson \& Weintraub, 2007). However, that it is important to study predator as natural enemy when considering control of T. urticae. In this prespective, studies on the sideeffects of pesticides should address both $P$. persimilis and its prey, T. urticae. A large number of publications have dealt with the effects of pesticides on T. urticae as it easily develops resistant strains to acaricides (Ako et al., 2004).Thus, some trials in laboratory and greenhouse to assess the effects of five acaricides against $T$. urticae and its natural enemy $P$. persimilis were conducted.

\section{MATERIALS AND METHODS}

\section{Rearing prey mite}

The two spotted spider mite, $T$. urticae was reared on kidney bean (Phaseolus vulgaris L.) planted in a greenhouse (3-4 weeks after germination), and maintained at $25-28^{\circ} \mathrm{C}, 40-60 \%$ R.H. with a photoperiod of $16 \mathrm{~L}: 8 \mathrm{D}(\mathrm{h})$.

\section{Rearing predatory mite}

The phytoseiid predator $P$. persimilis was reared in plastic tray $(25 \times 25 \mathrm{~cm})$ placed in a plastic box $(40 \times 60 \times 7 \mathrm{~cm})$ containing water to prevent mite escape. Fresh kidney bean leaves heavily infested with prey were supplied every 1 or 2 days and old leaves were removed once a week. $P$. persimilis rearing was conducted under laboratory conditions of $23 \pm 2{ }^{\circ} \mathrm{C}, 50-70 \%$ R.H. and L16:D8 photoperiod.

\section{Tested acaricides}

1- Ethion $\left(\right.$ Endo $^{\circledR} \quad 50 \%$ EC) IRAC $1 \mathrm{~B}$; organophosphate

Chemical name: $O, O, O^{\prime}, O^{\prime}$-tetraethyl $\mathrm{S}, \mathrm{S}^{\prime}$-methylene bis(phosphorodithioate), was obtained from Elhelb Pesticides and Chemicals Co.

2- Fenpyroximate (Ortus super ${ }^{\circledR} 5 \%$ EC) IRAC 21; METI 
Chemical name: tert-butyl(E)- $\alpha$-(1,3-dimethyl-5phenoxypyrazol-4-ylmethyleneaminooxy)-p-toluate, was obtained from Nichino America Ancorpurishn.

3- Etoxazole (Baroque ${ }^{\circledR} 10 \%$ SC) IRAC 10B; mite growth inhibitor

Chemical name: $(R S)$-5-tert-butyl-2-[2-(2,6-diflurophenyl)-4,5-dihydro-1,3-oxazol-4-yl]phenetole, was obtained from Sumitomo Chemical Co., Ltd.

4- Chlorfenapyr $\quad$ (Challenger $^{\circledR} \quad 36 \%$ SC) IRAC 13; arylpyrrole

Chemical name: 4-bromo-2-(4-chlorophenyl)-1ethoxymethyl -.5 trifluoromethyl.-1H-pyrrole-3carbonitrile, was obtained from BASF Corpor.

5- Abamectin $\quad$ Vertimec $^{\circledR} \quad 1.8 \% \quad$ EC) IRAC 6; avermectin

Chemical name: 5-O-demethylavermectin $\mathrm{A}_{1 \mathrm{a}}$ (i) mixture with 5-O-demethyl-25-de(1-methylpropyl)-25-(1-methylethyl)avermectin $\mathrm{A}_{1 \mathrm{a}}$ (ii), was obtained from Syngenta Agro.

\section{Bioassay techniques \\ Slide dip assay}

Tested acaricides concentrations were prepared from stock solutions in water. All concentrations were given as parts per million (ppm). A piece of double-sided adhesive tape was fixed to a microscope slide. A second piece of adhesive was placed, sticky side up, onto the double-sided tape. Ten female adults (one day old) of $T$. urticae and $P$. persimilis were then placed on their backs to each slide with a fine hair brush. At least six concentrations of each acaricide were used. Each concentration was replicated four times. Slides were dipped into $200 \mathrm{ml}$ beaker containing acaricides solutions so that the mites were immersed for five seconds to ensure complete wetting. Control mites were similarly dipped in water only. Thereafter, slides were touched down, on edge, on absorbent paper towelling and then allowed to dry under the laboratory conditions. After $24 \mathrm{~h}$, mites were examined, and incapable of moving an appendage when gently prodded with a fine brush were considered dead (Thistlewood et al., 1992 and SangGuei et al., 2002).

\section{Leaf disk dip assay}

The leaf disk assay was conducted using method described earlier by Pree et al., (1989). The kidney bean leaf disks $(2.5 \mathrm{~cm}$ diameter) cut from seedlings were dipped in concentrations of the various acaricides for 30 seconds. The discs were put on wet cotton wool in petri-dish and kept under constant conditions $\left(\left(25 \pm 2^{\circ} \mathrm{C}, 65 \pm 5 \%\right.\right.$ R.H. and 16:8 photoperiod). Ten female adults (one day old) of $T$. urticae were transferred on each disk with a fine brush. Concentration mortality regressions were based on tests with six concentrations of each acaricide, and were expressed as parts per million of active ingredient (a.i.). Control disks were dipped in tap water. Tests were repeated 4 times for each concentration of each acaricide. Mortality of mites treated with acaricides in all tests was assessed after 24 hrs.

In the two previous techniques, mortality data were corrected according to Abbott formula (1925), the corrected mortality percentage of each acaricide was statistically computed according to Finney (1971). The corresponding concentration probit lines (LC-p lines) were estimated in addition to determine 50 and $90 \%$ mortalities. Slope values of tested acaricides were estimated. In addition, the efficiency of different compounds was measured by comparing the tested compound with the most effective compound by using the equation of Sun (1950), toxicity index $=\mathrm{LC}_{50}$ of the most effective compound/LC $\mathrm{C}_{50}$ of the tested compound $\mathrm{x} 100$.

\section{Assessment of persistence and residual efficacy:}

The residual toxicity assays were conducted using methods described by Sáenz-de-Cabezòn et al., (2007). Each acaricide was tested at the concentration recommended for field applications according to Agricultural Pesticides Committee (APC 2010), Egypt as follow: ethion (Endo ${ }^{\circledR} 50 \%$ EC) at the rate of $600 \mathrm{ml} / \mathrm{feddan}\left(1 \mathrm{feddan}=4200 \mathrm{~m}^{2}\right)$ $=1500$ ppm; fenpyroximate (Ortus super ${ }^{\circledR} 5 \%$ EC) at the rate of $50 \mathrm{ml} / 100$ Liter $=25 \mathrm{ppm}$; etoxazole (Baroque ${ }^{\circledR} 10 \% \mathrm{SC}$ ) at the rate of $25 \mathrm{ml} / 100$ Liter $=25$ ppm; chlorfenapyr (Challenger ${ }^{\circledR} 36 \%$ SC) at the rate of $45 \mathrm{ml} / 100$ Liter $=162 \mathrm{ppm}$; abamectin $\left(\right.$ Vertimec $^{\circledR}$ $1.8 \% \mathrm{EC}$ ) at the rate of $40 \mathrm{ml} / 100$ Liter $=7.2 \mathrm{ppm}$.

A $100 \mathrm{ml}$ volume of each recommended concentration was sprayed on kidney bean $(P$. vulgaris) plants to run-off using a $200 \mathrm{ml}$ hand trigger sprayer with adjustable one nozzle set to mist position. Untreated plants were sprayed with distilled water alone. Five replicates were used for each treatment and the control. The plants were grown in a greenhouse at $25-28^{\circ} \mathrm{C}, 40-60 \%$ R.H. and a photophase of at least $16 \mathrm{~h}$ conditions. Drip irrigation and nutrients were applied uniformly to all plants and no pesticides were used prior to the experimental applications. Each bioassay unit consisted of five $20 \mathrm{~mm}$ diameter kidney bean leaf disks, cut with a cork borer from five treated and six untreated leafs removed from the plants. The disks were cleaned and placed on wet cotton wool inside a $90 \mathrm{~mm}$ diameter Petri dish. Additional water was added to prevent mite escape from the disks. 
Bioassays were conducted under constant conditions $\left(25 \pm 2^{\circ} \mathrm{C}, 65 \pm 5 \%\right.$ R.H. and $16: 8$ photoperiod).

Bioassays for $T$. urticae and $P$. persimilis were conducted in separate sets of bioassay units. Ten females of $T$. urticae were transferred on each disk with a fine brush. Mortality was recorded 24 hours after mites were placed on the disk. Six replicates of each acaricide treatment and control were conducted. Mites were considered dead if they were unable to react when gently probed with a fine brush. These procedures were repeated with treated and untreated leafs removed from the plants after $1,3,5,7$ and 9 days of application.

An adequate number of treated or untreated T. urticae females (25 active stages of $T$. urticae per 5 predator females) were transferred to each replicate as prey for $P$. persimilis. Mortality of $P$. persimilis was recorded after 24 hours after being placed a surplus of T. urticae on a disk in second trial. Six replicates (one bioassay unit) of each acaricide treatment and control were conducted. These procedures were followed at $1,3,5,7$ and 9 days after application. In both tests the half-life time values were computed by Ldp Line program.

\section{Effect of tested acaricides on population density:}

This experiment was conducted in a greenhouse planted with kidney bean $(P$. vulgaris $)$ at $25-28^{\circ} \mathrm{C}$, $40-60 \%$ RH with a photoperiod of $16: 8 \mathrm{~h}(\mathrm{~L}: \mathrm{D})$. Each acaricide was applied at the concentration suggested for field applications according to APC 2010, Egypt. Alive T. urticae and P. persimilis were counted and recorded at pre-spraying and after 1, 3, 5, 7 and 9 days of application. Lower surface of the leaves was examined carefully using stereomicroscope. Five replicates were used for each treatment and the control. Spray was applied using a hand sprayer with one nozzle sprayer of $200 \mathrm{ml}$ capacity. Percentage of reduction was estimated according to the equation of Henderson \& Tilton (1955).

\section{Statistical analysis}

Data of population density were subjected for one way analysis of variance (ANOVA), and the means were separated using Duncan's multiple range Test CoHort Software, (2004).

\section{RESULTS AND DISCUSSION}

\section{Comparison of bioassay techniques}

The toxicity of five tested acaricides to T. urticae using two techniques was represented in Table (1).
Generally, abamectin proved to be the most potent compound giving $\mathrm{LC}_{50}$ value of 0.031 and 0.122 ppm followed by fenpyroximate (3.21 and 4.29 ppm), ethion (23.38 and17.65 ppm), chlorfenapyr (12.55 and $87.69 \mathrm{ppm}$ ) and etoxazole (49.22 and $42.47 \mathrm{ppm}$ ) in slide dip and leaf disk dip techniques, respectively.

Toxicity index values showed the acaricidal effect of abamectin (100) on T. urticae compared with the other tested acaricides. These values reached $(0.966 \& 2.844 \%),(0.247 \& 0.139 \%)$, $(0.133 \& \quad \& \quad 0.691 \%)$ and $(0.063 \quad \& \quad 0.287 \%)$ for fenpyroximate, chlorfenapyr, ethion and etoxazole in slide dip and leaf disk dip techniques; respectively.

Table (2) indicated the toxicity of five tested acaricides to $P$. persimilis using slide dip technique. The results revealed the same trend of acaricides action on prey, also abamectin was the superior compound $\left(\mathrm{LC}_{50}=0.014 \mathrm{ppm}\right)$ followed by fenpyroximate $(2.56 \mathrm{ppm})$, chlorfenapyr (16.19 $\mathrm{ppm})$, ethion (36.90 $\mathrm{ppm}$ ) and etoxazole (94.92 ppm); respectively.

The abamectin was effective compound based on $100 \%$ mortality and the toxicity index of the other compounds were $0.547,0.086,0.038$ and $0.015 \%$ in case of fenpyroximate, chlorfenapyr, ethion and etoxazole; respectively.

\section{Evaluation of persistence and residual efficacy:}

Persistence of tested acaricides on kidney bean (P. vulgaris) planted in a greenhouse to $T$. urticae was shown in Table (3). Chlorfenapyr gave the greatest persistence $\left(\mathrm{LT}_{50}=4.99\right.$ days $)$, whereas ethion caused the smallest persistence $\left(\mathrm{LT}_{50}=2.61\right.$ days $)$. The tested acaricides were arranged in an ascending order of persistence (from the lowest to the highest persistence) as follows: ethion, fenpyroximate, etoxazole, abamectin and chlorfenapyr with persistence ratio $0.52,0.63$, $0.74,0.88$ and 1.00 fold; respectively.

Concerning the bioresidual efficacy on $P$. persimilis by feeding method with treated T. urticae at time intervals in days after application (Table 4), revealed the same trend of acaricides action on prey but was less effective on predatory. The persistence ratio of $P$. persimilis reached to $0.52,0.59,0.59,0.99$ and 1.00 folds for ethion, fenpyroximate, etoxazole, abamectin and chlorfenapyr; respectively. It is clear from previous data; the high persistence ratio was recorded with chlorfenapyr. 
Table (1): Toxicity of five tested acaricides to Tetranychus urticae Koch using two techniques.

\begin{tabular}{|c|c|c|c|c|c|c|}
\hline & Tested compounds & Ethion & Fenpyroximate & Etoxazole & Chlorfenapyr & Abamectin \\
\hline \multirow{4}{*}{$\begin{array}{l}\text { Slide dip } \\
\text { technique }\end{array}$} & $\begin{array}{c}\mathrm{LC50}(\mathrm{ppm}) \\
(\text { limits at 95\%) } \\
\end{array}$ & $\begin{array}{c}23.38 \\
(16.01-32.45) \\
\end{array}$ & $\begin{array}{c}3.21 \\
(2.16-4.47) \\
\end{array}$ & $\begin{array}{c}49.22 \\
(35.73-79.96) \\
\end{array}$ & $\begin{array}{c}12.55 \\
(6.16-25.57) \\
\end{array}$ & $\begin{array}{c}0.031 \\
(0.019-0.049) \\
\end{array}$ \\
\hline & $\begin{array}{c}\text { LC90(ppm) } \\
\text { (limits at 95\%) }\end{array}$ & $\begin{array}{c}165.94 \\
(99.83-406.85) \\
\end{array}$ & $\begin{array}{c}23.86 \\
(15.92-42.10) \\
\end{array}$ & $\begin{array}{c}360.93 \\
(176.60-1453.99) \\
\end{array}$ & $\begin{array}{c}1355.45 \\
(665.17-2762.06) \\
\end{array}$ & $\begin{array}{c}0.607 \\
(0.289-2.127) \\
\end{array}$ \\
\hline & Slope & $1.506 \pm 0.244$ & $1.471 \pm 0.175$ & $1.481 \pm 0.255$ & $0.630 \pm 0.120$ & $0.995 \pm 0.147$ \\
\hline & Toxicity index $(\%)$ & 0.133 & 0.966 & 0.063 & 0.247 & 100 \\
\hline \multirow{4}{*}{$\begin{array}{l}\text { Leaf disk } \\
\text { dip } \\
\text { technique }\end{array}$} & $\begin{array}{c}\text { LC50 (ppm) } \\
\text { (limits at 95\%) }\end{array}$ & $\begin{array}{c}17.65 \\
(3.53-32.68) \\
\end{array}$ & $\begin{array}{c}4.29 \\
(2.76-6.38) \\
\end{array}$ & $\begin{array}{c}42.47 \\
(30.93-68.09) \\
\end{array}$ & $\begin{array}{c}87.69 \\
(56.58-135.90) \\
\end{array}$ & $\begin{array}{c}0.122 \\
(0.08-0.181) \\
\end{array}$ \\
\hline & $\begin{array}{c}\mathrm{LC} 90(\mathrm{ppm}) \\
\text { (limits at 95\%) }\end{array}$ & $\begin{array}{c}316.48 \\
(168.59-1667.18)\end{array}$ & $\begin{array}{c}71.72(39.06- \\
181.25)\end{array}$ & $\begin{array}{c}312.25 \\
(146.19-2079.75)\end{array}$ & $\begin{array}{c}1154.99 \\
(745.28-1789.95)\end{array}$ & $\begin{array}{c}1.86 \\
(1.04-4.33)\end{array}$ \\
\hline & Slope & $1.022 \pm 0.266$ & $1.048 \pm 0.131$ & $1.479 \pm 0.335$ & $1.145 \pm 0.175$ & $1.084 \pm 0.126$ \\
\hline & Toxicity index $(\%)$ & 0.691 & 2.844 & 0.287 & 0.139 & 100 \\
\hline
\end{tabular}

Table (2): Toxicity of five tested acaricides to Phytoseiulus persimilis Athias-Henriot using slide dip technique

\begin{tabular}{lcccc}
\hline Tested compounds & $\mathrm{LC}_{50}(\mathrm{ppm})($ limits at 95\%) & $\mathrm{LC}_{90}(\mathrm{ppm})($ limits at 95\%) & Slope & Toxicity index $(\%)$ \\
\hline Ethion & $36.90(26.49-46.47)$ & $124.86(87.56-275.37)$ & $2.421 \pm 0.525$ & 0.038 \\
\hline Fenpyroximate & $2.56(1.41-3.84)$ & $26.74(16.86-55.49)$ & $1.258 \pm 0.191$ & 0.547 \\
\hline Etoxazole & $94.92(53.55-366.33)$ & $1906.86(450.14-103510)$ & $0.984 \pm 0.24$ & 0.015 \\
\hline Chlorfenapyr & $16.19(9.44-28.81)$ & $468.11(191.73-1957.12)$ & $0.877 \pm 0.118$ & 0.086 \\
\hline Abamectin & $0.014(0.009-0.022)$ & $0.20(0.127-0.314)$ & $1.112 \pm 0.162$ & 100.00 \\
\hline
\end{tabular}

Table (3): Persistence of tested acaricides on kidney bean (Phaseolus vulgaris L.) planted in a greenhouse to

Tetranychus urticae at time intervals in days after application.

\begin{tabular}{lccccccc}
\hline \multirow{2}{*}{$\begin{array}{l}\text { Tested } \\
\text { compounds }\end{array}$} & \multicolumn{6}{c}{ Mortality percentage after application (Days) } & \multicolumn{2}{c}{ Lt $_{50}$ (days) } & \multirow{2}{*}{ PR* } \\
\cline { 2 - 6 } Ethion & 1 & 3 & 5 & 7 & 9 & limits at 95\% & \\
\hline Fenpyroximate & 91.52 & 50.85 & 23.73 & 6.67 & 1.67 & $2.61(1.56-3.42)$ & 0.52 \\
\hline Etoxazole & 91.52 & 54.24 & 28.81 & 13.33 & 0.00 & $3.12(2.76-3.49)$ & 0.63 \\
\hline Chlorfenapyr & 89.83 & 76.27 & 33.90 & 16.67 & 0.00 & $3.68(3.06-4.43)$ & 0.74 \\
\hline Abamectin & 91.52 & 86.44 & 69.49 & 30.00 & 5.00 & $4.99(4.36-5.70)$ & 1.00 \\
\hline
\end{tabular}

* Persistence ratio (PR) compared with the highest persistence (Chlorfenapyr)

Table (4): The bioresidual efficacy on Phytoseiulus persimilis at time intervals in days after application.

\begin{tabular}{|c|c|c|c|c|c|c|c|}
\hline \multirow{2}{*}{$\begin{array}{c}\text { Tested } \\
\text { compounds }\end{array}$} & \multicolumn{5}{|c|}{ Mortality percentage after application (Days) } & \multirow{2}{*}{$\begin{array}{c}\mathrm{Lt}_{50} \text { (days) } \\
\text { (limits at } 95 \% \text { ) }\end{array}$} & \multirow{2}{*}{$\mathrm{PR}^{*}$} \\
\hline & 1 & 3 & 5 & 7 & 9 & & \\
\hline Ethion & 75.86 & 30.00 & 6.67 & 3.33 & 0.00 & $1.79(1.54-2.03)$ & 0.52 \\
\hline Fenpyroximate & 82.76 & 33.33 & 6.67 & 0.00 & 0.00 & $2.01(1.77-2.27)$ & 0.59 \\
\hline Etoxazole & 79.31 & 36.67 & 10.00 & 0.00 & 0.00 & $2.03(1.75-2.31)$ & 0.59 \\
\hline Chlorfenapyr & 86.21 & 86.67 & 30.00 & 6.67 & 3.33 & $3.42(2.79-4.19)$ & 1.00 \\
\hline Abamectin & 89.66 & 86.67 & 16.67 & 6.67 & 6.67 & $3.39(2.69-4.26)$ & 0.99 \\
\hline
\end{tabular}

* Persistence ratio (PR) compared with the highest bioresidual efficacy (Chlorfenapyr) 
Table (5): Efficiency of tested acaricides on population density of Tetranychus urticae at time intervals in days.

\begin{tabular}{|c|c|c|c|c|c|c|c|c|c|}
\hline \multicolumn{3}{|c|}{ Tested compounds } & \multirow{2}{*}{$\begin{array}{c}\text { Ethion } \\
12.72 \pm 3.59\end{array}$} & \multirow{2}{*}{$\begin{array}{c}\text { Fenpyroximate } \\
12.72 \pm 3.59 \\
\end{array}$} & \multirow{2}{*}{$\begin{array}{c}\text { Etoxazole } \\
12.72 \pm 3.59\end{array}$} & \multirow{2}{*}{$\frac{\text { Chlorfenapyr }}{12.96 \pm 3.96}$} & \multirow{2}{*}{$\begin{array}{l}\text { Abamectin } \\
13.12 \pm 3.71 \\
\end{array}$} & \multirow{2}{*}{$\begin{array}{l}\text { Control } \\
9.20 \pm 2.44\end{array}$} & \multirow[t]{2}{*}{ LSD 5\% } \\
\hline Pre-applica & & $\mathrm{M} \pm \mathrm{SD}$ & & & & & & & \\
\hline \multirow{10}{*}{$\begin{array}{l}\text { Mean } \\
\text { number per } \\
\text { leaf and } \\
\text { percent of } \\
\text { reduction } \\
\text { after } \\
\text { application } \\
\text { (days) }\end{array}$} & \multirow{2}{*}{1} & $\mathrm{M} \pm \mathrm{SD}$ & $1.16 \pm 1.55 \mathrm{~b}$ & $0.92 \pm 1.29 \mathrm{~b}$ & $0.96 \pm 1.40 \mathrm{~b}$ & $2.40 \pm 1.78 \mathrm{~b}$ & $1.24 \pm 1.61 \mathrm{~b}$ & $12.40 \pm 3.80 \mathrm{a}$ & 1.572 \\
\hline & & $\% \mathrm{R}$ & 93.23 & 94.63 & 94.4 & 86.26 & 92.99 & - & \\
\hline & \multirow{2}{*}{3} & $\mathrm{M} \pm \mathrm{SD}$ & $2.96 \pm 2.65 b c$ & $3.36 \pm 2.51 b c$ & $2.44 \pm 1.98 \mathrm{c}$ & $0.96 \pm 1.37 \mathrm{c}$ & $5.16 \pm 1.62 b$ & $14.80 \pm 4.56 \mathrm{a}$ & 2.242 \\
\hline & & $\% \mathrm{R}$ & 85.53 & 83.58 & 88.07 & 95.4 & 75.55 & - & \\
\hline & \multirow{2}{*}{5} & $\mathrm{M} \pm \mathrm{SD}$ & $7.92 \pm 3.50 \mathrm{c}$ & $10.60 \pm 2.93 b$ & $3.92 \pm 2.11 \mathrm{~d}$ & $2.60 \pm 2.50 \mathrm{~d}$ & $11.12 \pm 3.29 b$ & $19.20 \pm 5.32 \mathrm{a}$ & 2.115 \\
\hline & & $\% \mathrm{R}$ & 70.17 & 60.07 & 85.23 & 90.39 & 59.39 & - & \\
\hline & \multirow{2}{*}{7} & $\mathrm{M} \pm \mathrm{SD}$ & $15.28 \pm 4.06 \mathrm{bc}$ & $17.08 \pm 5.14 b$ & $13.20 \pm 3.83 \mathrm{~cd}$ & $11.04 \pm 2.75 \mathrm{~d}$ & $15.80 \pm 3.59 b c$ & $21.04 \pm 6.11 \mathrm{a}$ & 2.704 \\
\hline & & $\% \mathrm{R}$ & 47.47 & 41.29 & 54.62 & 62.75 & 47.34 & - & \\
\hline & \multirow{2}{*}{9} & $\mathrm{M} \pm \mathrm{SD}$ & $22.20 \pm 7.75 \mathrm{a}$ & $21.52 \pm 6.71 \mathrm{ab}$ & $20.88 \pm 6.20 \mathrm{ab}$ & $15.92 \pm 4.71 \mathrm{c}$ & $17.76 \pm 4.72 b c$ & $23.24 \pm 10.20 \mathrm{a}$ & 4.051 \\
\hline & & $\% \mathrm{R}$ & 30.91 & 33.03 & 35.02 & 51.37 & 46.41 & - & \\
\hline \multicolumn{3}{|c|}{ General mean of $\%$ reduction } & 65.46 & 62.52 & 71.47 & 77.23 & 64.34 & - & \\
\hline
\end{tabular}

Table (6): Efficiency of tested acaricides on population density of Phytoseiulus persimilis at time intervals in days.

\begin{tabular}{|c|c|c|c|c|c|c|c|c|c|}
\hline \multicolumn{3}{|c|}{ Tested compounds } & Ethion & Fenpyroximate & Etoxazole & Chlorfenapyr & Abamectin & Control & LSD $5 \%$ \\
\hline \multicolumn{3}{|c|}{ Pre-application $\mathrm{M} \pm \mathrm{SD}$} & $6.36 \pm 2.67$ & $6.36 \pm 2.67$ & $6.36 \pm 2.67$ & $6.36 \pm 2.67$ & $6.36 \pm 2.67$ & $4.76 \pm 1.98$ & \\
\hline \multirow{10}{*}{$\begin{array}{c}\text { Mean } \\
\text { number } \\
\text { per leaf } \\
\text { and } \\
\text { percent of } \\
\text { reduction } \\
\text { after } \\
\text { applicatio } \\
\text { n (days) }\end{array}$} & \multirow{2}{*}{1} & $\mathrm{M} \pm \mathrm{SD}$ & $0.32 \pm 0.55 \mathrm{bc}$ & $0.84 \pm 1.18 \mathrm{bc}$ & $0.96 \pm 1.34 \mathrm{~b}$ & $0.64 \pm 0.86 \mathrm{bc}$ & $0.24 \pm 0.52 \mathrm{c}$ & $3.92 \pm 1.68 \mathrm{a}$ & 0.621 \\
\hline & & $\% \mathrm{R}$ & 93.89 & 83.96 & 81.67 & 87.78 & 95.42 & - & \\
\hline & & $\mathrm{M} \pm \mathrm{SD}$ & $0.84 \pm 0.90 \mathrm{c}$ & $2.16 \pm 1.40 \mathrm{~b}$ & $1.08 \pm 1.29 \mathrm{c}$ & $0.64 \pm 0.95 \mathrm{c}$ & $0.56 \pm 0.92 \mathrm{c}$ & $6.00 \pm 2.06 \mathrm{a}$ & 0.716 \\
\hline & & $\% \mathrm{R}$ & 89.52 & 73.06 & 88.91 & 92.02 & 93.01 & - & \\
\hline & & $\mathrm{M} \pm \mathrm{SD}$ & $2.56 \pm 1.16 \mathrm{c}$ & $3.72 \pm 1.54 \mathrm{~b}$ & $2.16 \pm 1.75 \mathrm{c}$ & $1.88 \pm 1.67 \mathrm{c}$ & $2.40 \pm 1.94 \mathrm{c}$ & $7.40 \pm 2.78 \mathrm{a}$ & 1.049 \\
\hline & & $\% \mathrm{R}$ & 74.11 & 62.38 & 78.15 & 80.99 & 75.73 & - & \\
\hline & & $\mathrm{M} \pm \mathrm{SD}$ & $3.12 \pm 0.97 \mathrm{~d}$ & $5.68 \pm 2.11 \mathrm{~b}$ & $5.44 \pm 1.78 \mathrm{~b}$ & $4.32 \pm 1.93 \mathrm{c}$ & $3.92 \pm 1.73 \mathrm{~cd}$ & $8.20 \pm 2.10 \mathrm{a}$ & 0.887 \\
\hline & & $\% \mathrm{R}$ & 71.52 & 48.16 & 50.35 & 60.57 & 64.22 & - & \\
\hline & \multirow{2}{*}{9} & $\mathrm{M} \pm \mathrm{SD}$ & $4.48 \pm 2.04 \mathrm{c}$ & $11.16 \pm 3.51 \mathrm{a}$ & $11.16 \pm 2.53 \mathrm{a}$ & $9.88 \pm 2.86 \mathrm{a}$ & $7.60 \pm 3.41 \mathrm{~b}$ & $11.20 \pm 3.49 \mathrm{a}$ & \\
\hline & & $\% \mathrm{R}$ & 70.06 & 25.69 & 25.42 & 33.98 & 49.21 & - & \\
\hline \multicolumn{4}{|c|}{ General mean of \% reduction 79.82} & 58.65 & 64.9 & 71.07 & 75.52 & - & \\
\hline
\end{tabular}

Table (7): Comparison between the two used techniques on Tetranychus urticae

\begin{tabular}{llll}
\hline $\begin{array}{c}\text { Tested } \\
\text { compounds }\end{array}$ & Technique & $\begin{array}{l}\mathrm{LC}_{50} \\
(\mathrm{ppm})\end{array}$ & $\begin{array}{l}\text { Toxicity } \\
\text { index }(\%)\end{array}$ \\
\hline \multirow{2}{*}{ Ethion } & Slide dip & 23.38 & 75.58 \\
\cline { 2 - 4 } & Leaf disk dip & 17.65 & 100.00 \\
\hline \multirow{2}{*}{ Fenpyroximate } & Slide dip & 3.21 & 100.00 \\
\cline { 2 - 4 } & Leaf disk dip & 4.29 & 74.80 \\
\hline \multirow{2}{*}{ Etoxazole } & Slide dip & 49.22 & 79.96 \\
\cline { 2 - 4 } & Leaf disk dip & 42.47 & 100.00 \\
\hline \multirow{2}{*}{ Chlorfenapyr } & Slide dip & 12.55 & 100.00 \\
\cline { 2 - 4 } & Leaf disk dip & 87.69 & 14.31 \\
\hline \multirow{2}{*}{ Abamectin } & Slide dip & 0.03 & 100.00 \\
\cline { 2 - 4 } & Leaf disk dip & 0.12 & 25.41 \\
\hline
\end{tabular}

Table (8): Comparison between the toxicity of acaricides to Tetranychus urticae and Phytoseiulus persimilis

\begin{tabular}{llll}
\hline $\begin{array}{c}\text { Tested } \\
\text { compounds }\end{array}$ & $\begin{array}{c}\text { Prey and } \\
\text { predatory mites }\end{array}$ & $\begin{array}{c}\mathrm{LC}_{50} \\
(\mathrm{ppm})\end{array}$ & $\begin{array}{l}\text { Toxicity } \\
\text { index }(\%)\end{array}$ \\
\hline \multirow{2}{*}{ Ethion } & T. urticae & 23.38 & 100.00 \\
\cline { 2 - 4 } Fenpyroximate & P.persimilis & 36.90 & 63.35 \\
\cline { 2 - 4 } Etoxazole & T. urticae & 3.21 & 79.71 \\
\hline \multirow{2}{*}{ Chlorfenapyr } & T. urticae & 49.22 & 100.00 \\
\cline { 2 - 4 } & P. persimilis & 94.92 & 51.85 \\
\cline { 2 - 4 } Abamectin & P. perticae & 12.55 & 100.00 \\
\cline { 2 - 4 } & T. urticae & 0.031 & 45.16 \\
\hline
\end{tabular}




\section{Efficiency of tested acaricides on population density:}

Table (5) showed that the initial and residual effect of tested acaricides against $T$. urticae infestation. Concerning the initial effect (after one day of spraying), no significant differences were obtained among all tested acaricides. After three days, there were significant differences in the effects of tested acaricides. The effects of chlorfenapyr and etoxazole were most striking, which caused 95.40 and $88.07 \%$ reduction; respectively. The most effective compound till the end of the experiment was chlorfenapyr, which caused $51.37 \%$ reduction at the ninth day. The efficiency of the tested acaricides could be arranged according to the general mean of reduction percentage in a descending order as follows: chlorfenapyr, etoxazole, ethion, abamectin and fenpyroximate they were $77.23,71.47,65.46,64.34$ and $62.52 \%$ ;respectively.

All treatments reduced the population density of the predatory mite $P$. persimilis, with significant differences between treatments and the control (Table 6). Abamectin had the highest initial effect (95.42\% reduction); while the lowest was obtained with etoxazole, $81.67 \%$ reduction in population density than control, after one day from application. After 9 days from application, significant differences did not emerge between etoxazole, fenpyroximate, chlorfenapyr and control. On the other hand fenpyroximate showed the lowest general mean of reduction percentage in population density of $P$. persimilis than control, recording $58.65 \%$ reduction. An ascending order of the rest toxicants was etoxazole (64.90\%), chlorfenapyr (71.07\%), abamectin $(75.52 \%)$ and ethion $(79.82 \%)$.

The slide dip technique provides efficient method against $T$. urticae for testing abamectin, chlorfenapyr and fenpyroximate, but the leaf disk dip technique was more efficient method for determining the toxicity of ethion and etoxazole. The difference between the compounds and some of them may be due to the difference in mode of action of each compound (Table 7).

For this reason, it is important to be fully aware with the mode of action of acaricide before choosing the best bioassay technique to assess acaricides. Our studies largely concentrated on acaricides representing distinctly different primary target sites of action. The mode of action of chosen acaricides to study initially were ethion IRAC 1B, organophosphate, an inhibitor of acetylcholinesterase, non-systemic with predominantly contact action; fenpyroximate
IRAC 21, mitochondrial electron transport inhibitors (METI) at Complex I (Hirata et al., 1995), quick knockdown activity against larvae, nymphs and adults, mainly by contact and ingestion, also some moulting inhibitory activity on nymphs; etoxazole IRAC 10B, mite growth inhibitor was determined to be chitin biosynthesis inhibition (Nauen \& Smagghe, 2006), contact with effect on eggs, larvae and nymphs, with no effect on adults; chlorfenapyr IRAC 13, arylpyrrole, inhibitor and uncoupler of the oxidative phosphorylation, mainly stomach and some contact action, exhibits good translaminar, but limited systemic; abamectin IRAC 6, avermectin, primary mode of action is to block synaptic transmission, a chloride channel activator (GABA agonist), contact and stomach action (Decombe et al., 2004). However, the survival rate of T. urticae adult females in treatment with etoxazole was much higher than those of the other acaricidal treatments (Kim \& Yoo 2002). Reports have shown that etoxazole interfere with the molting process of mite juvenile stages and have little effect against adults (Anderson et al., 1986; Sumitomo Chemical 1995).

The present results indicate that for the strains tested, ethion, chlorfenapyr and etoxazole are much less toxic to $P$. persimilis adult females than to $T$. urticae adult females (Table 8). Kim \& Yoo, (2002) showed that survival at $168 \mathrm{~h}$ after treatment with etoxazole was $86 \%$ for $P$. persimilis adult females and $66 \%$ for those of T. urticae. Thus, etoxazole was also less toxic to adult female predators than to their prey, also chlorfenapyr could be used as selective acaricide in integrated mite management program because it is more toxic to T. urticae than to P. persimilis (Zhang \& Sanderson, 1990). Moreover, they reported that feeding on $T$. urticae intoxicated with abamectin reduced $50 \%$ of the reproductive rate of $P$. persimilis female.

In addition, the predators alone may not be able to maintain spider mite populations below an economic injury level for an extended period of time (Kim et al., 1997 and Ibrahim \& Yee 2000). In the presence of chemical applications, biological control of spider mites may be achieved by the selective use of the pesticides that are more toxic to pest species than to natural enemies (Spollen \& Isman 1996). Thus, selective acaricides are needed to adjust the prey/predator ratio and to maintain adequate longterm control efficacy.

\section{REFERENCES}

Abbott W.S. 1925. A method of computing the effectiveness of an insecticide. J. Econ. Entomol., 18: 265 - 267. 
Ako, M.; Borgemeister, C.; Poehling, H.M.; Elbert, A. and Nauen, R. 2004. Effects of neonicotinoids insecticides on the bionomics of two spotted spider mite (Acari: Tetranychidae). J. Econ. Entomol., 97, 1587-1594.

Anderson, M.; Fisher, J. P.; Robinson, J. and Debray, P. H. 1986. Flufenoxuron: an acylurea acaricide/ insecticide with novel properties. In: Proceedings, 1986 British Crop Protection Conference-Pests and Diseases, British Crop Protection Council, Brighton, England: 89-96.

APC .2010. Agricultural Pesticides Committee, Ministry of Agriculture, Egypt. http://www.apc. gov.eg. Accessed 25 February 2010.

Cohort Software 2004. CoStat. www.cohort. com.Monterey, California,USA.

Croft, B.A. 1990. Arthropod Biological Control Agents and Pesticides. John Wiley, New York.

Decombel, L.; Smagghe, G. and Tirry, L. 2004. Action of major insecticide groups on insect cell lines of the beet armyworm, Spodoptera exigua, compared with larvicidal toxicity. In Vitro Cellular, Developmental Biology - Animal, 40: 2 43-51.

Finney, D.J. 1971. Probit analysis. A Statistical Treatment of the Sigmoid Response Curve. 7th Ed., Cambridge Univ. Press, England.

Gerson, U.; Smiley, R.L. and Ochoa, R. 2003. Mites (Acari) for Pest Control. Blackwell Science, Malden USA.

Gerson, U. and Weintraub, P.G. 2007. Mites for the control of pests in protected cultivation. Pest Management Science, 63: 658-676.

Helle, W. and Sabelis, M.W. 1985. Spider mites. Their biology, natural enemies and control, vol. 1A. Elsevier, Amsterdam, Oxford, New York, Tokio.

Henderson, C.F. and Tilton, E.W. 1955. Test with acaricides against the brown wheat mite. J. Econ. Entomol., 48: 157-161.

Hirata, K.; Kawamura, Y.; Kuno, M. and Igarasgi, H. 1995. Development of a new acaricide, pyridaben. J Pestic Sci., 20:177-179.

Hoy, M.A. 1985. Improving establishment of arthropod natural enemies. In: Hoy, M.A.; Herzog, D.C. (Eds.), Biological Control in Agricultural IPM Systems. Academic Press, INC., Orlando, Florida: 151-166.

Hoy, M.A.; Cunningham, G.L. and Knutson, L. 1983. Biological Control of Pests by Mites. Univ. Calif. Div. Agric. Nat. Res. Publ., 3304, Berkeley, CA.

Ibrahim, Y.B. and Yee, T.S. 2000. Influence of sublethal exposure to abamectin on the biological performance of Neoseiulus longispinosus (Acari: Phytoseiidae). J. Econ. Entomol., 93: 1085-1089.

Kim, S.S. and Yoo, S.S. 2002. Comparative toxicity of some acaricides to the predatory mite, Phytoseiulus persimilis and the two spotted spider mite, Tetranychus urticae Bio.Control .,47: 563-573.

Kim, D.I.; Lee, S.C.; Paik, C.H.; Kim, S.S. and Ma, K.C. 1997. Population fluctuation of Tetranychus kanzawai and their natural enemies and related susceptibility of some pesticides to Amblyseius womersleyi and T. kanzawai. J. Kor. Tea Soc., 3: 83-93.

Mcmurtry, J.A. 1982. The use of phytoseiids for biological control: progress and future prospects. In: Hoy, M.A. (Ed.), Recent Advances in Knowledge of the Phytoseiidae, Univ. Calif. Div. Agric. Nat. Res. Publ., 3284, Berkeley, CA, pp. 23-48.

Mcmurtry, J.A.; Huffaker, C.B. and Van De Vrie, M. 1970. Ecology of tetranychid mites and their natural enemies: a review. 1. Tetranychid enemies, their biological characteristics and the impact of spray practices. Hilgardia, 40: 331390.

Nauen, R. and Smagghe, G. 2006. Mode of action of etoxazole. Pest. Manag. Sci., 62: 379-382.

Pree, D.L.; Cole, K.J. and Fisher, P.A. 1989. Comparison of leaf disc and Petri dish assays for the assessment of dicofol resistance in populations of European red mite (Acari: Tetranychidae) from southern Ontario. Can. Entomol., 12: 771-776.

Sáenz-De-Cabezòn, F.J.I.; Zalom, F.G. and Thompson, P.B. 2007. Residual toxicity of acaricides to Galendromus occidentalis and Phytoseiulus persimilis reproductive potential. Bio. Con., 40: 153-159.

Sang-Guei, L.E.E.; Stephanie, A.; Hilton, A.; Bruce, B. and Jeong-Hwan, K.I.M. 2002. Insecticide Resistance in Phytoseiid Predatory Mites, Phytoseiulus persimilis and Amblyseius cucumeris (Acarina: Phytoseiidae). J. AsiaPacific Entomol., 5 (1): 123 -129.

Spollen, K.M. and Isman, M.B. 1996. Acute and sublethal effects of a neem insecticide on the commercial biological control agents Phytoseiulus persimilis and Amblyseius cucumeris (Acari: Phytoseiidae) and Aphidoletes aphidimyza (Diptera: Cecidomyiidae). J. Econ. Entomol., 89: 1379-1386.

Sumitomo Chemical 1995. S-1283 (etoxazole). A new selective acaricide, technical information, 26 pp.

Sun, Y.P. 1950. Toxicity index an improved method 
of comparing the relative toxicity of insecticides. J. Econ. Entomol., 43:45-53.

Thistlewood, H.M.A.; Pree, D.J. and Crawford, L.A. 1992. Comparison of slide dip and petri dish assays for measuring resistance to pennethrin in Amblyseius fallacis (Acari: Phytoseiidae), J.
Econ. Entomol., 85: 2051-2057.

Zhang, Z.Q. and Sanderson, J.P. 1990. Relative toxicity of abamectin to the predatory mite, Phytoseiulus persimilis (Acari: Phytoseiidae) and two spotted spider mite (Acari: Tetranychidae). J. Econ. Entomol., 83: 1783-1790. 